\title{
EXTENSION OF THE RAGUSAN AQUEDUCT FROM THE SPRING IN KNEŽICA, 1518-1520: COMMON CONCERN OF THE GOVERNMENT AND PEOPLE FOR THE COMMON GOOD
}

\author{
Zdenka Janeković Römer
}

\author{
Z. Janeković Römer \\ Zavod za povijesne znanosti HAZU u Dubrovniku \\ Lapadska obala 6, Dubrovnik \\ Vojnovićeva 19, HR-10000 Zagreb \\ zdenka.janekovic-roemer@zg.ht.hr
}

\begin{abstract}
The archives of the Dubrovnik Republic file a codex containing data on the connection of the Knežica spring with the main aqueduct in 1518-1520 which has not been used in the studies of Dubrovnik's water supply to date. The data from this small volume reveal the community's efforts to improve the water supply of the city. The construction and maintenance of the water supply system involved many citizens and inhabitants, from noble overseers, engineers, master builders and craftsmen to workers and peasants. The Ragusan government played an essential role in this collective project by ensuring the people's right to natural resources, that is, to the common good-happiness and welfare of the citizens. This meant the achievement of the medieval ideal of good government and well-governed community, a theme introduced to Croatian historiography by Igor Fiskovic. Good government makes the city an ideal society whose main purpose is liberty, happiness and well-being of its citizens. The office-holders', citizens and inhabitants duty to the public welfare was at the basis of the Ragusan social consensus, civil self-consciousness and patriotism which strengthened the power of the community and stood as the basis of the Republic's continuity.
\end{abstract}

Key words: Middle Ages, Dubrovnik Republic, common good, aqueduct, Knežica spring

In his praise of Dubrovnik and its governors written in 1440, Philippus de Diversis enthused about the aqueduct which carried fresh drinking water to the city from the rich natural springs of Šmet: "In the earlier times this city was not lavishly supplied with the sweetest of liquids, nor was it embellished with an aqueduct, as in my time... Nowadays, however, Dubrovnik has a wealth of fresh spring water that flows 8,000 paces and in generous quantities streams into the city... Oh, what a beneficial pledge for the protection of the homeland! Such an achievement and such investment ought to be recommended to memory for time and all eternity. What other thing could be of greater benefit or whatever worthier of memory could have been done?"1 A century and a half later, (1595) Serafino Razzi, fascinated with the abundance of water flowing into the city, commended the Ragusan government for having prudently invested its ducats, for their city was still enjoying their copious fruits. ${ }^{2}$ Water supply was of vital importance for the quality of life in the medieval city - water was needed for drinking, cooking, washing and cleaning, for crafts, maintenance of public hygiene and fire protection. Before the construction of the aqueduct, the city was supplied

\footnotetext{
"This research was supported by a grant from the Croatian Science Foundation (no. 5106).

${ }^{1}$ F. de DIVERSIS, Opis slavnoga grada Dubrovnika 1440, Z. JANEKOVIĆ RÖMER (ed., trans.), Zagreb, 2004, pp. 43, 142.

${ }^{2}$ Serafino RAZZI, La storia di Ragusa: scritta nuovamente in 3 libri, Giuseppe GELCICH (ed.), Dubrovnik, 1903, 90.
} 
with water from the tanks and wells, as well as from the springs in Mlini and Ombla, fresh water being carried to the city by boats. ${ }^{3}$ By the early fifteenth century, the current water resources could no longer accommodate the growing economic and demographic needs of the city. The supplies of drinking water did not meet the needs in either quantity or quality, and craft manufacturers could not operate unless having large supplies of water. In the fifteenth century, the Dubrovnik Republic was well equipped with organisational tools which enabled it to embark upon a challenging project such as that of the aqueduct construction. The Republic had stone masons, builders who knew how to make canals and conduits, and was in a position to commission engineering experts in hydraulic technology, Andreuccio Bulbito and Onofrio dela Cava from Naples. They built the aqueduct from the spring of Vrelo in Sumet, 11,700 metres in length, reservoirs and watering holes along the route, as well as the two fountains in the city. The work was completed in two years (1436-1438). ${ }^{4}$ The city was thus supplied with fresh, crystal clear spring water, void of earthy, salty taste and the stale smell of well water or rainwater from the tanks, in other words with the water whose quality was recommended by the ancient and medieval medical treatises. ${ }^{5}$

The complex water systems based on sophisticated hydraulic technology required great investment in terms of labour and money, technical knowledge and natural resources. A system of this kind required a continuous common effort on the maintenance which included organisation structures, management, supervision and laws. The construction and maintenance of the aqueduct involved all the social strata, from councillors, overseers, engineers, master builders, craftsmen, wageworkers and all the inhabitants of the city and its environs. The water supply system was a common good of the inhabitants and they joined forces to build and maintain it. The government provided an administrative and financial framework which facilitated the improvement of the city infrastructure - and with it the rise of the living standard, as well as the development of cloth manufacture, milling, tanning and other crafts. ${ }^{6}$

The city's increasing water needs soon exceeded the current capacity of the water supply system, because of which many workshops were relocated to the mouth of Ombla. Thus in the course of the fifteenth century the government was already reconsidering the possibility to have some other natural springs tapped to the aqueduct. The archives of the Dubrovnik Republic file a small codex with data on the connection of the Knežica spring (later Bota) to the main aqueduct (1518 - 1520) which has not been employed in the studies of the Ragusan aqueduct to date. ${ }^{7}$ The codex data reveal the efforts of the government and the whole community on the improvement of the water supply. The idea of tapping the Knežica spring to the aqueduct was first recorded in the autumn of 1453. Upon the proposition of the Consilium Rogatorum, three noblemen were appointed to inquire into the possibility of connecting the spring to the aqueduct on the estate of Ser Frano Benessa, his brother and Ser Vukša de Babalio. A month later, a decision to embark upon this project was voted out. The project proposition included the construction of a mile long tapping canal, a span high and a span wide $(25,6$ $\mathrm{x} 25,6)$. By means of conduits built of tile and brick it was to be connected with four smaller springs

\footnotetext{
${ }^{3}$ Cf. E. WHITNEY, Medieval Science and Technology. Westport, 2004, p. 117.

${ }^{4}$ On construction of the water supply see: L. BERITIĆ, Dubrovački vodovod, in Anali Historijskog instituta u Dubrovniku 8-9, Dubrovnik, 1962, pp. 9-100; On technical characteristics of the water supply see: R. SEFEROVIĆ, M. STOJAN, The Miracle of Water: Prolegomena to the Early Renaissance Aqueduct of Dubrovnik, Dubrovnik Annals 11, Dubrovnik, 2007, pp. 53-84; U. C. EWERT, Water, Public Hygiene and Fire Control in Medieval Towns: Facing Collective Goods Problems while Ensuring the Quality of Life, in Historical Social Research 32, 4, Leibniz, 2007, p. 224.

${ }^{5}$ Cf. F. MANTELLI, G. TEMPORELLI, L' acqua nella storia, Milano, 2008, pp. 114-115, 152-153;

${ }^{6}$ L. BERITIĆ, op. cit., pp. 101, 105-106; State Archives in Dubrovnik (SAD), Acta Consilii Rogatorum (ACR), ser. 3, vol. 8, ff. 183'-185, vol. 9, f. 179; Acta Consilii Minoris (ACMin), ser. 5, vol. 20, ff. 90, 105-106; Diversa Notariae (DN), vol. 22, ff. 132'-133; R. SEFEROVIĆ, M. STOJAN, op. cit., pp. 71-75.

${ }^{7} \mathrm{SAD}$, Fabbrichae, ser. 7, vol. 1, Lo primo octobre 1519 presentato per officiali de far condur acqua chiamada Chnesiça in 10 canal de la fontana, ff. 41/1.
} 
in the vicinity. ${ }^{8}$ Half of the expenses were to be covered by the commune, and the other half by the leaseholders of the mills, tanneries, textile and other workshops. Concern for the common welfare was not only manifested in joint financing but also in a decision to build troughs by all the springs so as to meet the water needs of the neighbouring villages. ${ }^{9}$ Tapping of two additional springs - V rečevo (Račevica) and Orahovac-was also considered. By 1462, Bartul Graciano, protomagister of the aqueduct and fountains, proposed a better connection of the Vrečevo spring with the aqueduct and certain improvements regarding water filtration, this topic being again on the agenda in $1488 .{ }^{10}$ In 1491 Bartol Radohnić and Marin Vukčić submitted a contract offer for the springs of Knežica, Orahovac and Vrečevo for a remuneration of 150 perpers, in addition to the maintenance of the aqueduct and fountains for a salary of 55 perpers a year. ${ }^{11}$ In 1509 and 1513, the Consilium Rogatorum elected a commission consisting of three noblemen with a task of solving the tapping of Knežica to the main water supply route. ${ }^{12}$ This issue was again on the agenda in 1518. godine - three noblemen were sent to survey the terrain of the future aqueduct route. The Senate then authorised the overseers to open the works. ${ }^{13}$

The works on the section from Knežica to the main canal, no more than $1.3 \mathrm{~km}$ long, lasted from the end of 1518 to the beginning of 1521. The overseer of works, Ser Dimitrius, son of Simon de Benessa, and the head of the officials of the aqueduct construction, Ser Raphael, son of Nicola de Gozze $^{14}$, contracted builders from Korčula, Slano, Šumet and the neighbouring places. Certain groups of builders promised to build between 50 and 100 or even more paces of the canal at a price of 30 grossi per pace. The formwork was paid 13 grossi per pace. ${ }^{15}$ Organised groups transported thousands of modia of stone and clay to the site, large poles for the formwork, along with hundreds of modia of lime, gravel and sand for the mortar. The construction site was equipped with nails, ties, beams, planks from Senj and Venice, wooden vessels and barrels in which mortar was mixed. ${ }^{16}$ A noble name has been traced in the supply of lime, that of Ser Jeronim, son of Frano de Pozza, who sold his lime at a higher price than the others, with a comment that he would not agree to less. ${ }^{17}$ The codex also mentions Ser Dominic, son of Nicola de Pozza from whom the overseers of the works obtained the planks from Venice. ${ }^{18}$

${ }^{8}$ ACR, vol. 16, f. 160; D. ROLLER, Dubrovački zanati u XV. i XVI. stoljé́u (Građa za gospodarsku povijest Hrvatske 2). Zagreb, 1951, p. 107; L. BERITIĆ, op. cit., p. 102.

${ }^{9}$ ACR, vol. 13, ff. 251', 262'-263'; DN, vol. 25, f. 188; Liber viridis (Zbornik za istoriju, jezik i književnost srpskog naroda, dpt. 3, bk. 23) (Liber viridis), B. NEDELJKOVIĆ (ed.), Beograd, 1984., c. 438.

${ }^{10}$ ACMin, vol. 13, ff. 7-8; L. BERITIĆ, op. cit., p. 103.

${ }^{11}$ ACR, vol. 26, ff. 202-202'; R. JEREMIĆ, J. TADIĆ, Prilozi za istoriju zdravstvene kulture starog Dubrovnika (Prilozi), Beograd, 1939, vol. 3, p. 26; L. BERITIĆ, op. cit., p. 103.

${ }^{12}$ ACR, vol. 31, f. 135; vol. 32, f. 286'; L. BERITIĆ, op. cit., p. 103.

${ }^{13}$ ACR, vol. 34, ff. 277'-278; vol. 35, ff. 25'-26, 296-297; vol. 36, ff. 4'-5; L. BERITIĆ, op. cit., pp. 103-105.

${ }^{14}$ Fabbrichae, vol. 1: front cover, f. 18'; Ser Dimitrius, son of Simon de Benessa $\left({ }^{*} 1475\right)$ had been engaged on similar duties pertaining to communal works and payment, in Ston mainly, and he was also appointed castellan of Mali Ston, count of Mljet and captain of Cavtat. Ser Raphael, son of Nicola de Gozze ( ${ }^{*} 1468$ - †1532) held offices in charge of the salt trade, customs, private attorney, wool trade, castellan of Coruna, procurator of Slano, count of Lastovo, justice of the Appelate Court. Manuali pratici del cancelliere, ser. 21.1, vol. 1, Indice Magistrature ed officiali nunc Specchio del Maggior Consiglio dictum, 1440-149 (Specchio, vol. 1), passim.

${ }^{15}$ Fabbrichae, vol. 1: ff. 15-15'-16, 17', 18'-19, 19'-20.

${ }^{16}$ Ibidem, front cover, ff. 16'-17, 20'-21, 24', 25', 31', 35-38; Cf. R. SEFEROVIĆ, M. STOJAN, op. cit., pp. 58, 64-66; D. ESPOSITO, Tecniche costruttive murarie medievali. Murature "a tufelli" in area romana. Storia della tecnica edilizia e restauro dei monumenti, Roma, 1998, p. 83.

${ }^{17}$ Fabbrichae, vol. 1, front cover, f. 21. Nobleman Jeronim, son of Frano de Pozza, born around 1472, entered the council in 1492. He was in charge of Hospitale misericordiae, state's grain supply and was count of Šipan. Specchio, vol. 1, passim.

${ }^{18}$ Nobleman Dominic, son of Nicola de Pozza $\left({ }^{*} 1464\right.$ - †1521) was in charge of Hospitale misericordiae, was overseer of public accounts, appraiser, official responsible for the state's salt supply, camerlengo (official bursar), cazamorto 
Collateral benefit from the aqueduct for the inhabitants of Šumet, Slano, Ombla, Zaton, Ston, Kaludraci ${ }^{19}$ was employment - public works recruited a large number of people, as evidenced by the proportion of salaries in the overall expenditures. The codex contains a list of 82 persons by name, from noblemen to protomagistri, masons, hauliers and labouring hands. Yet the number of workmen was much greater - the codex notes only the names of the master builders and section foremen to whom the overseers paid out salaries. ${ }^{20}$ Also mentioned are the workmen from the kaznačine ${ }^{21}$ who were recruited when necessary - they dug out canals at 15 follari a week. Only in the summer of 1519 as many as 3,052 contracts with the diggers on one-week basis were made. One week witnessed between 198 and 583 workmen being engaged on the canal for a total payment of 148 perpers. ${ }^{22}$ The workmen were given food and wine - the latter was supplied by the counts of Ombla and Župa, while the other expenses were covered by the overseers. Entered among the expenditures were also serving dishes, tables and a pergolata, an arbor for the midday break. ${ }^{23}$ Master builders and wageworkers could make a reasonable earning, particularly if qualified. Protomagister Matko received the highest wage of 6 grossi per day, a total of 17 perpers and 6 grossi. Stone masons, from Korčula mainly, were also paid well, their salaries being up to 25 ducats. The surveyor, member of the distinguished citizen confraternity of St Anthony, Stephen, son of Nicola Nale ${ }^{24}$, who was responsible for the levelling of the canal and who on several occasions measured the terrain and the route's length, earned 6 perpers and 8 grossi. ${ }^{25}$ Master builders were paid 4 to 5 grossi per day, scribe 4 grossi, conscript soldiers (barabanti), guards and unqualified builders 2-3 grossi, diggers and auxillary workers 1-1.5 grossi. Carpenters (marangoni) and messengers were paid by the work done, while hauliers by the quantity of the material delivered. ${ }^{26}$ Some works involved even children (puti) - the codex mentions 15 children who worked 281 days for one grosso per day and earned 23 perpers and 5 grossi. ${ }^{27}$ Every few days the overseers Benessa and Gozze made payments according to the seal-authorised receipts (poliza bulata). ${ }^{28}$ Recorded in the codex is a total expenditure of 4,348 perpers, 10 grossi and 17 follari for the material expenses, labour fees and spese de bocha. The expenditures were recorded in double entry bookkeeping, the data also being entered into the books of the Debita notariae. ${ }^{29}$ Income and expenses were also supervised by the overseers of public accounts, for the year 1519 they were Andreas, son of Michael de Resti, Vita, son of Nicola de Zamagno, Valentin, son of Franco de Sorgo, Antun, son of Andreas de Benessa and Givo, son of Jeronim de Babalio, and for 1520 Stephen, son of Simon de Benessa, Michael, son of Luca Sorgo, Demetrius, son of Matheus de Ragnina and Pasqua, son of Trajan de Crieva. ${ }^{30}$

(responsible for public health and measures against plague). He was also Rector's aide, procurator of the convent of St Clare and St Mary of Angels, justice of the Appelate Court and member of the Consilium Rogatorum (Senate) and Minor Council. Manuali pratici del cancelliere, ser. 21.1, Indice Magistrature ed officiali nunc Specchio del Maggior Consiglio dictum, 1500-1599 (Specchio, vol. 2), passim; Fabbrichae, vol. 1, f. 31'.

${ }^{19}$ Matko Gjivanović and his mates from Kaludraci on the island of Šipan delivered stone to the construction site. On the Graeco-Byzantine toponym Kaludraci see: Josip Lučić, Prošlost elafitskog otoka Šipana (do 1300.), Starohrvatska prosvjeta 3, 10, Zagreb, 1968, 104.

${ }^{20}$ Ibidem, ff. 22-22', 23.

${ }^{21}$ Local administrative units.

22 Ibidem, ff. 23, 24'.

${ }^{23}$ Ibidem, ff. 21', 31'.

${ }^{24} \mathrm{SAD}$, Ostavština Čingrija, Vlajkijeva genealogija Antunina, sig. RO 161, f. 35.

${ }^{25}$ Fabbrichae, vol. 1, f. 41.

${ }^{26}$ Ibidem, ff. 22-25, 31'.

${ }^{27}$ Ibidem, f. 23.

${ }^{28}$ Ibidem, ff. 1, 21'; a tergo 1.

${ }^{29}$ Ibidem, ff. 1', 15, 15', 16, 18'-19.

${ }^{30}$ Specchio, vol. 2, passim. Fabbrichae, vol. 1, front cover. 
The Ragusan aqueduct fell within the type of the medieval gravity aqueducts. The systems of this kind had been used in monasteries and cities from as early as the twelfth century, and by the late medieval period were technically perfected. ${ }^{31}$ They required high maintenance costs and collective activity - it was a clear example of cooperation between individual and community for the common welfare. ${ }^{32}$ The aqueduct's infrastructure - canals, ditches, cisterns, grooves along with the conduits that carried water to the fountains, mills and other plants-needed regular cleaning, protection from damage and pollution, as well as protection of the waterway route from unauthorised usage. By 1436, the Consilium Rogatorum had prescribed punishments for those who would damage the aqueduct or take water unlawfully from it for their own use, their cattle or watering of their gardens. In the course of the aqueduct construction, a supervising commission was elected - three senators, men who had experience in construction works. They contracted and supervised the works, and were in charge of evaluation and disbursement. Once the aqueduct was completed, their daily duty was to survey the whole route and organise the repair of the canals and mills. The number of the surveyors - as many as five of them- suggests the difficulty and scope of their duty. ${ }^{33}$ In 1440 the Consilium Rogatorum introduced a special office of the supervisor of water supplies. ${ }^{34}$ The first law regulating the supervision of the aqueduct was passed in 1443, which prohibited any unlawful opening of the aqueduct for the purpose of watering cattle, crops and wool washing. The punishment which protected the common interest before individual was drastic - amputation of the right hand. If the offender was not found, the punishment became collective - all the neighbours were to pay the fine. Individuals were held responsible for accidental damages of the aqueduct - every person whose garden or field was overflown by the water from the aqueduct was to report it to the Minor Council within eight days on pain of a fine of 25 perpers. In addition to the noblemen elected on the Major Council, the aqueduct was also surveyed by a mason - protomagister of the aqueduct, whose daily duty was to survey along the aqueduct's route and repair the eventual damages. ${ }^{35}$ In 1545 Pasqua of Naples was admitted to service as protomagister of the aqueduct, at a monthly salary of 15 ducats. The provision on the supervision of the aqueduct issued by the Consilium Rogatorum on 21 October 1550 reveals the zeal with which the government attended to the common good of all inhabitants and expected their cooperation on it. On this very date the provisores read out the report on the new and old aqueduct before the council. It was decided that the overseers were to inspect in person the springs in Knežica, Orahovac and Vrečevo, make certain that the canals had been built according to professional rules and standards, and to look for damages or flaws if any. The canals had to be inspected along the whole route, notably the sections under marshes or those vulnerable to winter torrents. They were to evaluate whether the water nearby filtered into the canals, how solidly founded were the arches used to traverse the depressions and whether they were in danger of collapsing. The canal's route was designated on either side so that the owners of the bordering plots could know where to build walls and plant trees. All trees suspected of causing damage to the canal and springs were to be cut down and rooted out at the cost of the land owner on pain of a 25 perper fine. Unlawful use of water from the canal for home or garden purposes was also fined. The overseers measured the depth

\footnotetext{
${ }^{31}$ E. WHITNEY, op. cit., p. 121; R. J. MAGNUSSON, Water Technology in the Middle Ages. Cities, Monasteries, and Waterworks after the Roman Empire, Baltimore, 2001, pp. 116-132.

${ }^{32}$ Cf. Mancur OLSON, The Logic of Collective Action. Public Goods and the Theory of Groups, Cambridge, MA, 1971, pp. 5-6.

${ }^{33}$ ACR, vol. 6, ff. 65, 65', 70'-71, 73, 75', 77', 78', 79. Specchio, vol. 2, passim; SAD, Diversa cancellariae, ser. 25, vol. 52, ff. 70-72; vol. 7, f. 168, vol. 24, f. 142'; R. SEFEROVIĆ, M. STOJAN, op. cit., pp. 56-60, 62-63.

${ }^{34}$ Ibidem, p. 65; ACR, vol. 7, f. 202; S. M. CERVA, Prolegomena in sacram metropolim Ragusinam, editio princeps, R. SEFEROVIĆ (ed.), 2008, p. 315.

${ }^{35}$ Liber viridis, c. 341; R. JEREMIĆ, J. TADIĆ, Prilozi, vol. 1, p. 43, vol. 3, pp. 22-23; ACMin, vol. 7, ff. 86'-87; L. BERITIĆ, op. cit., p. 102.
} 
of water at the spring, in the canals and reservoirs, inspected mills and fulling mills in Ombla and in the city, and reported on it to the Consilium Rogatorum. ${ }^{36}$ The terrain along which the aqueduct descended the slopes of Mount Srd was owned by the state so as to ensure better supervision and protection, and also prevent any construction. ${ }^{37}$ The Senate brought similar measures later, with even higher fines for unlawful use of water from the canal, which in 1621 reached as many as 100 ducats. ${ }^{38}$ The damage caused by the disastrous earthquake of 1667 could only be restored by the community's joint efforts. Water supply was among the government's priorities, and special provisions regarding this issue were passed shortly after the earthquake. ${ }^{39}$

The aqueduct carrying water from the Knežica spring was particularly demanding in terms of maintenance because it was laid on fossil landslide. Recurrent damages required regular repair and reconstruction at the cost of the whole community. One of these reconstructions was carried out after 1545 by protomagister Pasqua, with two of his assistants. The section running through the marshy terrain and landslides near Knežica required particular attention, where the arches and the canal could easily suffer damage. Four noblemen, supervisors of water supplies, were to consult protomagister Pasko about the width of the path between the aqueduct and the bordering plots, and about the actual water discharge from the spring to the entrance into the old reservoir and the last stops of the aqueduct. Special measures for the protection of that vulnerable section of the aqueduct were also passed after the earthquake of $1667 .{ }^{40}$

The construction of the aqueduct was of major social significance not only because of the improvement of living standard and industrial development but also as an expression of unity. The aqueduct changed the city's image and brought better living conditions and comfort to its citizens. Lavish water supply is one of the symbols of an ideal city - it stands for urban culture, and in the case of medieval Europe, Christian symbolism should also be attached to it. ${ }^{41}$ In the Middle Ages water was not regarded as a trade product but as a common good belonging to every man. Like other natural resources, water was understood as a God's gift to man who has a right to enjoy it without compensation. The objective of a good government was to secure this right to its citizens. ${ }^{42}$ Concern for common welfare tells of the living standard and safety in the cities, but equally so of the government which governs these goods and the whole community itself. The projects ensuring common good, especially those such as aqueduct which required paramount costs and maintenance efforts, show the government's determination towards common goals and welfare. A government founded on these principles meant the fulfilment of the medieval ideal of good government and well governed community, a topic introduced to Croatian historiography by Igor Fisković. Good government, guided primarily by liberty, happiness and well-being of its citizens, makes a city an ideal society. ${ }^{43}$ Not only by laws and regulations but also by securing material and non-material

\footnotetext{
${ }^{36}$ ACR, vol. 49, ff. 234-236; R. JEREMIĆ, J. TADIĆ, Prilozi, vol. 3, pp. 27-29.

${ }^{37}$ L. BERITIĆ, op. cit., p. 121.

${ }^{38}$ ACR, vol. 87, ff. 214'-215; L. BERITIĆ, op. cit., p. 104.

${ }^{39}$ Ibidem, 106.

${ }^{40}$ R. JEREMIĆ, J. TADIĆ, Prilozi, vol. 3, pp. 27-29; ACR, vol. 49, ff. 234-236, 250; L. BERITIĆ, op. cit., pp. 104, 106.

${ }^{41}$ P. SQUITRITTI, Water and society in early medieval Italy. AD 400-1000, Cambridge, 1998, pp. 18-19; B. C. L. Rothauser, "A reuer... brighter pen bope the sunne and mone": The Use of Water in the Medieval Consideration of Urban Space, in Urban Space in the Middle Ages an the Early Modern Age, A. CLASSEN (ed.), Berlin, 2009, pp. 245-272: 245, 255; R. MAGNUSSON, op. cit., pp. xi-xii.

${ }^{42}$ J. ABERTH, An Environmental History of the Middle Ages: The Crucible of Nature, London, 2013, p. 32.

${ }^{43}$ I. FISKOVIĆ, Dubrovnik u mijenama stila 15. stoljéca na Jadranu, in: Likovna kultura Dubrovnika 15. i 16. stoljeća. Znanstveni skup uz izložbu Zlatno doba Dubrovnika, I. Fisković (ed.), Zagreb, 1991, p. 25; Idem, O značenju i porijeklu renesansnih reljefa na portalu Kneževa dvora, in Igor Fisković, Reljef renesansnog Dubrovnika, Dubrovnik, 1993, pp.
} 
goods to its citizens, the government promoted civil virtues, patriotism and social consensus. ${ }^{44}$ An office-holder's citizens and inhabitants duty to the common good was in the foundations of the Ragusan social consensus, civil self-consciousness, solidarity and patriotism which strengthened the community and represented the basis of the Republic's continuity.

\section{DOGRADNJA DUBROVAČKOG VODOVODA OD IZVORA KNEŽICA 1518-1520: VLAST I PUK U ZAJEDNIČKOJ SKRBI ZA OPĆE DOBRO}

U arhivu Dubrovačke Republike čuva se kodeks nastao tijekom radova na povezivanju izvora Knežica s glavnim vodovodom, 1518.-1520. godine, koji nije korišten u dosadašnjim radovima o vodovodu. Podaci iz te knjižice otkrivaju napor zajednice na zajedničkom dobru poboljšanja opskrbe grada vodom. Krajem 1518. godine trojica plemića poslani su na teren da utvrde kuda će i preko čijeg zemljišta prolaziti trasa vodovoda. Potom je Senat dao ovlaštenje nadzornicima radova da počnu s poslom. Radovi na dionici vodovoda od Knežice do glavnog kanala, dugoj tek 1,3 km, trajali su od kraja 1518. do početka 1521. godine. Nadglednik radova Dimitrije Šimunov Benessa i voditelj službenika za izgradnju vodovoda Rafael Nikolin Gozze ugovarali su poslove s meštrima zidarima s Korčule, iz Slanog, Sumeta i okolnih mjesta. Okolno stanovništvo dovozilo je i materijal za gradnju: kamen, kolce, daske, glinu, kreč, šljunak, pijesak, čavle, vezice, zdjele za mort i slično. U tom poslu sudjelovala su i neka vlastela.

Javni radovi na vodovodu zapošljavali su veliki broj ljudi. U kodeksu se poimence spominju 82 osobe, od vlastele, do protomagistra, zidara, peljara i najamnika no broj radnika je bio daleko veći knjižica bilježi samo imena predvodnika radnih skupina koji su organizirali radnike i ubirali zaradu za njih. Spominju se i radnici iz kaznačina koje su pozivali na rad po potrebi. Tijekom ljeta 1519. spominje se čak 3052 ugovora s kopačima na po tjedan dana. Iz navoda knjižice vidi se da su meštri i najamnici mogli lijepo zaraditi na tom poslu, osobito nadzornici, protomagistri, mjernici, kvalificirani zidari i klesari. Nešto niže plaće imali su kopači, marangoni, pisari, barabanti i stražari i vozari. Marangoni su bili plaćeni po poslu, a prevozitelji po količini dovezenog materijala. U nekim radovima sudjelovala su i djeca. U kodeksu je ubilježeno ukupno 4348 perpera 10 groša i 17 folara izdataka za materijalne troškove, plaće, hranu i piće.

Održavanje dubrovačkog vodovoda bilo je skupo i zahtijevalo je kolektivnu akciju - to je bio jasan primjer suradnje pojedinaca i zajednice na opću dobrobit. Stari vodovod s izvora Knežica bio je posebno zahtjevan za održavanje jer se nalazio na fosilnom klizištu. Zbog čestih oštećenja, stalno ga je trebalo popravljati i obnavljati, što je iziskivalo veliki napor čitave zajednice. Izgradnja vodovoda imala je i veliko društveno značenje, ne samo zbog podizanja standarda života i proizvodnje nego i kao iskaz zajedništva. Izobilje vode jedan je od simbola idealnoga grada - ono označuje urbanu kulturu, a kad se radi o europskom srednjovjekovlju, tome se pridodaje i kršćanska simbolika. U srednjem vijeku voda nije bila roba nego opće dobro koje pripada svakome čovjeku. Kao i drugi prirodni resursi, voda je bila shvaćena kao Božji dar čovjeku koji ga ima pravo uživati bez plaćanja. Zadatak dobre vlade bio je da osigura građanima to pravo. Osiguranje javnih dobara, posebno onih koji su, kao vodovod, iziskivali vrlo velike troškove i napor oko održavanja, pokazuje koliko je vlast posvećena zajedničkim ciljevima i općem dobru. To je značilo ostvarenje srednjovjekovnog ideala dobre vlasti i dobro upravljane zajednice, teme koju je u hrvatsku historiografiju uveo Igor Fisković. Dobra uprava

\footnotetext{
144-148; Idem, Povijesni biljezi dubrovačkog identiteta, Dubrovnik 4, Dubrovnik, 1993, pp. 94-95; Idem, Antički motivi u simbolici dubrovačke državnosti, in Umjetnost na istočnoj obali Jadrana u kontekstu europske tradicije: zbornik radova sa znanstvenog skupa održanog u Opatiji u svibnju 1992, posvećenog djelu prof. dr. Radmile Matejčić, N. KUDIŠ, M. VICELJA (eds.), Rijeka, 1993, pp. 219-222.

${ }^{44}$ R. BLANTON, L. FARGHER, Collective Action in the Formation of Pre-Modern States, New York, 2008, p. 20.
} 
čini grad idealnim društvom kojemu je glavna svrha sloboda, sreća i blagostanje građana. Služenje službenika vlasti, građana i stanovnika općoj dobrobiti bilo je u temelju dubrovačkog društvenog sporazuma, građanske samosvijesti i domoljublja koje je osnaživalo snagu zajednice i bilo temelj trajnosti Republike.

Ključne riječi: srednji vijek, Dubrovačka republika, opće dobro, akvedukt, izvor Knežica 